\title{
Investigation of Equivalent Circuit Model for a 5G Microstrip Patch Antenna
}

\author{
Bilal Aghoutane ${ }^{1}$, Mohammed El Ghzaoui², Hanan El Faylali¹, Sudipta Das ${ }^{3}$ \\ ${ }^{1}$ ISO Laboratory, Department of Computer Science, IbnTofail University, Kenitra, Morocco \\ 2 Sidi Mohamed Ben Abdellah University, Faculty of Sciences, Fes, Morocco \\ ${ }^{3}$ Department of ECE, IMPS College of Engineering and Technology, W.B., India
}

(Received 10 January 2021; revised manuscript received 14 June 2021; published online 25 June 2021)

\begin{abstract}
In recent years, we are witnessing an exponential development of new applications and technologies in the fields of health, media, industry, transport, energy. This evolution goes hand in hand with the emergence of new services related to a multiplication of connected objects. Faced with these challenges, a new revolution is coming with a new standard of mobile telecommunications systems, referred to as 5G technology. This work presents an investigation of an equivalent circuit model for a $5 \mathrm{G}$ microstrip patch antenna. The purpose of this paper is to model an antenna with electrical circuit. In this direction, the proposed antenna was designed by two methods then compared in term of $S_{11}$. Firstly, the antenna was designed by HFSS (High Frequency Structure Simulator) software. Then, the same antenna was designed by an equivalent circuit by using the optimization tool in ADS (Advanced design system) software. The results obtained from the two softwares were compared in terms of the reflection coefficient, i.e., $S_{11}$. It has been demonstrated that the results from ADS are in good agreement with those from HFSS. Other parameters are discussed in this paper such as VSWR (Voltage Standing Wave Ratio), $E$-plane and $H$-plane of the proposed antenna and real and imaginary part of input impedance of the proposed antenna. From simulation results, we can conclude that the proposed equivalent circuit is validated by mean of simulations.
\end{abstract}

Keywords: Antenna, 5G applications, Equivalent circuit, Reflection coefficient.

DOI: 10.21272/jnep.13(3).03036

PACS number: 84.40.Ba

\section{INTRODUCTION}

Throughout history, man has never ceased to find new means for communication (hand gestures, smoke signals, written document, etc.). Through successive eras the human being has provided intellectual and physical efforts in order to discover adequate methods of communication. The effort of humanity for centuries has borne fruit with the innovation of the electric telegraph in 1895 where for the first time in the history of telecommunications one could communicate almost instantly between two relatively distant points.

However, recent years have witnessed unprecedented developments in telecommunications systems. Multi-function systems are emerging as a relevant solution for recent communications systems, to ensure reliable transmission. Among the most used systems are OFDM (Orthogonal Frequency Division Multiplexing) modulation [1, 2], MIMO (Multi Input Multi Output) technique $[3,4]$ and antennas [5-7]. These techniques give rise to new technologies, such as $4 \mathrm{G}, 5 \mathrm{G}$ or currently terahertz technology [8]. In this work, we will be interested in the antenna part that plays a very important role in the communication chain.

The objective of this paper is to propose an equivalent circuit for an antenna for the $5 \mathrm{G}$ applications. It is in this sense, that we first started by designing our antenna with HFSS then the proposed antenna will be simulated with ADS. Indeed, in low frequency resonant circuits are used to provide a selective frequency, the value of this frequency depends on the values of the impedances constituting the resonant circuit. For the similar purpose, they are used in this work to generate a high frequency that meets the need. Microwave resonant circuits are based on microstrip line, whose geo- metric shape of the line is equivalent to an oscillating circuit consisting of passive components. Thus, the proposed antenna will be designed and simulated by ADS and HFSS. The results found by the two softwares will be compared in terms of $S_{11}$.

\section{THE PROPOSED RECONFIGURABLE ANTENNA DESIGN}

\subsection{The Layout Model of the Proposed Antenna}

The proposed antenna configuration designed on FR4 substrate with the dimension of $37.752 \times 26.821 \mathrm{~mm}^{2}$ is presented in Fig. 1. The antenna geometry comprise two iterations of rectangular slot loaded of $8.938 \times 2.852625 \mathrm{~mm}^{2}$ in the rectangular patch. Also, on the right and left of patch is loaded with added a parasitic triangle resonator of $\approx 46.32 \mathrm{~mm}^{2}$. Furthermore, the partial rectangular ground plane of proposed geometry is loaded with a modified slot and a parasitic circular ring resonator of radius $5.9 \mathrm{~mm}$.

The geometrical dimensions of the basic patch can be calculated as follows [10]:

$$
\begin{gathered}
\mathrm{W}_{\mathrm{p}}=\frac{\mathrm{c}}{2 \mathrm{f}_{\mathrm{c}} \sqrt{\frac{\varepsilon_{\text {relative }}+1}{2}}}, \\
\varepsilon_{\text {eff }}=\frac{\varepsilon_{\text {relative }}+1}{2}+\frac{\varepsilon_{\text {relative }}-1}{2}\left(\frac{1}{\sqrt{1+12\left(\frac{h}{W_{p}}\right)}}\right), \\
\Delta L=0.421 h \frac{\left(\varepsilon_{\text {eff }}+0.3\right)\left(\frac{W_{p}}{h}+0.264\right)}{\left(\varepsilon_{\text {eff }}-0.258\right)\left(\frac{W_{p}}{h}+0.8\right)},
\end{gathered}
$$




$$
L_{p}=\frac{c}{2 f_{c \sqrt{\varepsilon_{e f f}}}}-2 \Delta L,
$$

where, $W_{p}$ and $L_{p}$ represents patch's width and length, respectively, $h$ is the height of the substrate, $\varepsilon_{\text {eff }}$ and $\varepsilon_{\text {ralative }}$ are the effective and relative permittivity of substrate respectively. $c, f_{c}$ and $\Delta L$ are the speed of light, central frequency, and the effective length, respectively. The main feed line is matched by an impedance of $50 \mathrm{Ohm}$. For impedance matching during modeling, the following transmission line characteristic equations are considered [10]. For $\frac{W_{f}}{H} \leq 1$,

$$
Z_{0}=\frac{60}{\varepsilon_{\text {reff }}} \ln \left[\frac{8 H}{W_{f}}+\frac{W_{f}}{4 H}\right] \text {, }
$$

where

$$
\varepsilon_{\text {reff }}=\frac{\varepsilon_{r}+1}{2}+\frac{\varepsilon_{r}-1}{2}\left(\frac{1}{\sqrt{1+12 \frac{H}{W_{f}}}}+0.04\left(1-\frac{W_{f}}{H}\right)^{2}\right)
$$

For $\frac{W_{f}}{H} \geq 1$,

$$
Z_{0}=\frac{120 \pi \sqrt{\varepsilon_{r e f f}}}{\frac{W_{f}}{H}+1.393+0.667 \ln \left(\frac{W_{f}}{H}+1.444\right)},
$$

where

$\varepsilon_{\text {reff }}=\frac{\varepsilon_{r}+1}{2}+\frac{\varepsilon_{r}-1}{2}\left(\frac{1}{\sqrt{1+12 \frac{H}{W_{f}}}}+0.04\left(1-12 \frac{H}{W_{f}}\right)^{-\frac{1}{2}}\right)$,

where $W_{f}$ is the width of the feed line and $Z_{0}$ is the characteristic impedance of the transmission line. For calculation of the width and length $L_{f}$ of the feed network, Eqs. (9)-(11) are used:

$$
\begin{gathered}
W_{f}=\frac{2 h}{\pi}, \\
\left(B-1 \ln (2 B-1)+\frac{\varepsilon_{r}-1}{2 \varepsilon_{r}}\left[\ln (B-1)+0.39-\frac{0.61}{\varepsilon_{r}}\right]\right), \\
L_{f}=\frac{\lambda}{4 \sqrt{\varepsilon_{r e f f}}}, \\
B=\frac{60 \pi^{2}}{Z_{0} \sqrt{\varepsilon_{r}}},
\end{gathered}
$$

where $B$ is a constant used in the inverse design formula, expressed in Eq. (9) for a microstrip line of a given characteristic impedance.

The antenna geometry and the optimized value of the parameters have been presented in Fig. 1 and Table 1 , respectively.
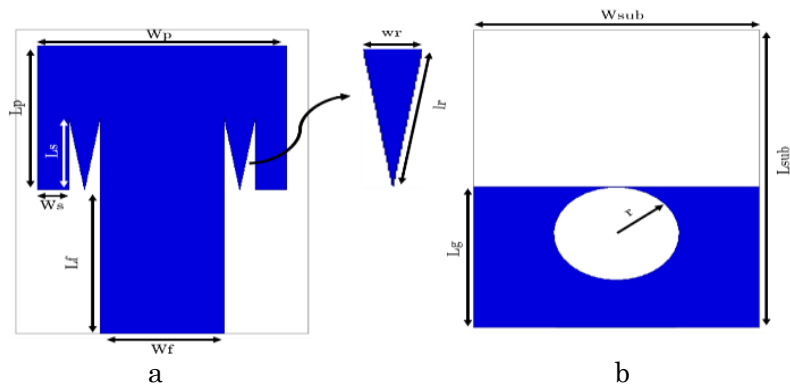

Fig. 1 - The 5G antenna geometry proposed: (a) top view and (b) bottom view
Table 1 - The optimized dimensions of the proposed antenna (in $\mathrm{mm}$ )

\begin{tabular}{|c|c|c|c|c|}
\hline Parameters & $\boldsymbol{W}_{\boldsymbol{p}}$ & $\boldsymbol{L}_{\boldsymbol{p}}$ & $\boldsymbol{W}_{\boldsymbol{f}}$ & $\boldsymbol{L}_{\boldsymbol{f}}$ \\
\hline Dimensions & 22.821 & 17.876 & 11.4105 & 17.876 \\
\hline Parameters & $\boldsymbol{W}_{\boldsymbol{s}}$ & $\boldsymbol{L}_{\boldsymbol{s}}$ & $\boldsymbol{W}_{\boldsymbol{r}}$ & $\boldsymbol{L}_{\boldsymbol{r}}$ \\
\hline \multirow{2}{*}{ Dimensions } & 2.8526 & \multirow{2}{*}{8.938} & 2.8526 & 10.364 \\
& 25 & & 25 & 3125 \\
\hline Parameters & $\boldsymbol{L}_{\boldsymbol{g}}$ & $\boldsymbol{L}_{\boldsymbol{s u b}}$ & $\boldsymbol{W}_{\boldsymbol{s u b}}$ & $\boldsymbol{r}$ \\
\hline Dimensions & 17.876 & 37.752 & 26.821 & 5.9 \\
\hline
\end{tabular}

\subsection{The Equivalent Circuit Model of the Proposed Antenna}

An equivalent model located for a microstrip line antenna can be derived from the conventional hypothesis of microstrip line elements in terms of $R$ resistance, $L$ inductance, $C$ capacity and $G$ conductance [10]. In antennas, any conductive element is approached as a serial combination of $R$ and $L$ because it has $R$ resistance and $L$ induction due to conductivity. The $R$ resistance represents driver losses. In microstrip line antennas, as the upper and lower conductive layers are separated by a dielectric material, a parallel combination of $C$-capacity and $G$ conductance is assumed in shunt. It is obvious that a certain capacity emerges when two conductors are separated by a dielectric material and $G$ is considered due to dielectric loss. Sometimes a spot of induction is also considered between the upper and lower layers to account for fringing fields and surface waves. Taking this induction into account results in better accuracy in the approximation of the localized equivalent model. This section initially presents a conventional approach to modeling an equivalent circuit model for a basic patch antenna as shown by Fig. 1. However, the radiant patch can be circular, trapezoidal, square or any other shape without slits or notches. He then explains how the same approach is extended to the proposed antennas.

As mentioned earlier, in the antennas, each conductor forms a series combination of $R$ and $L$. Thus, in the microstrip antenna, the three elements, i.e., microstrip feed line, radiating patch and ground layer also for three series combinations of $R$ and $L$. However, the series combination of $R$ and $L$ of the mass layer is overlooked due to the negligible current flow compared to the upper conductor. In the antenna, the top layer composed of two conducting elements as feed line and radiating patch.

In general, the microstrip patch antenna is similar to an open-ended transmission line. The microstrip patch, microstrip line feed and their equivalent circuits are depicted in Fig. 2.

The $C, L$, and $R$ values which match the frequency of the microstrip patch antenna can be calculated as follows, respectively.

$$
\begin{gathered}
C=\frac{d W_{\varepsilon_{0} \varepsilon_{e f f}}}{2 h} \cos ^{-2}\left(\frac{\pi y_{0}}{d}\right), \\
L=\frac{1}{(2 \pi f)^{2} C}, \\
R=\frac{1}{2 \pi f C},
\end{gathered}
$$


where $y_{0}$ is the feed point location, $Q$ is the quality factor of the resonator calculated as in Eq. (15):

$$
Q=\frac{c \sqrt{\varepsilon_{e f f}}}{2 f h} .
$$

The values of $L_{f}$ and $C_{f}$ in the equivalent circuit of the microstrip line feed are given by Eqs. (16) and (17):

$$
\begin{gathered}
L_{f}=100 h\left(4 \sqrt{\frac{W_{f}}{h-4.21}}\right)(n H), \\
C_{f}=W_{f}\left[\left(9.5 \varepsilon_{r}+1.25\right) \frac{W_{f}}{h}+5.2 \varepsilon_{r}+7\right](p F) .
\end{gathered}
$$
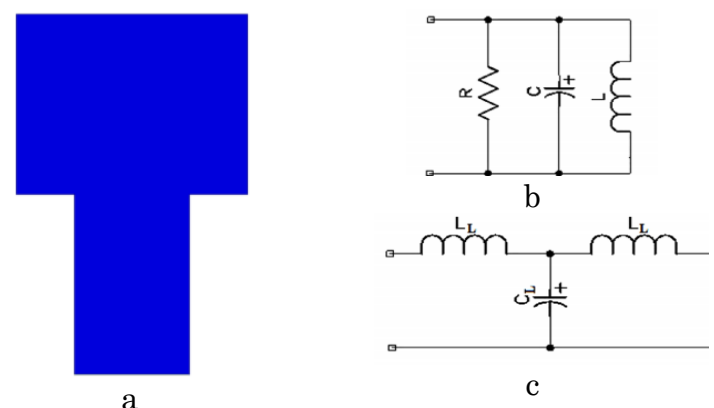

Fig. 2 - Microstrip antenna and its equivalent circuit: (a) microstrip patch antenna with microstrip line feed; (b) microstrip patch equivalent circuit; (c) microstrip line feed equivalent circuit

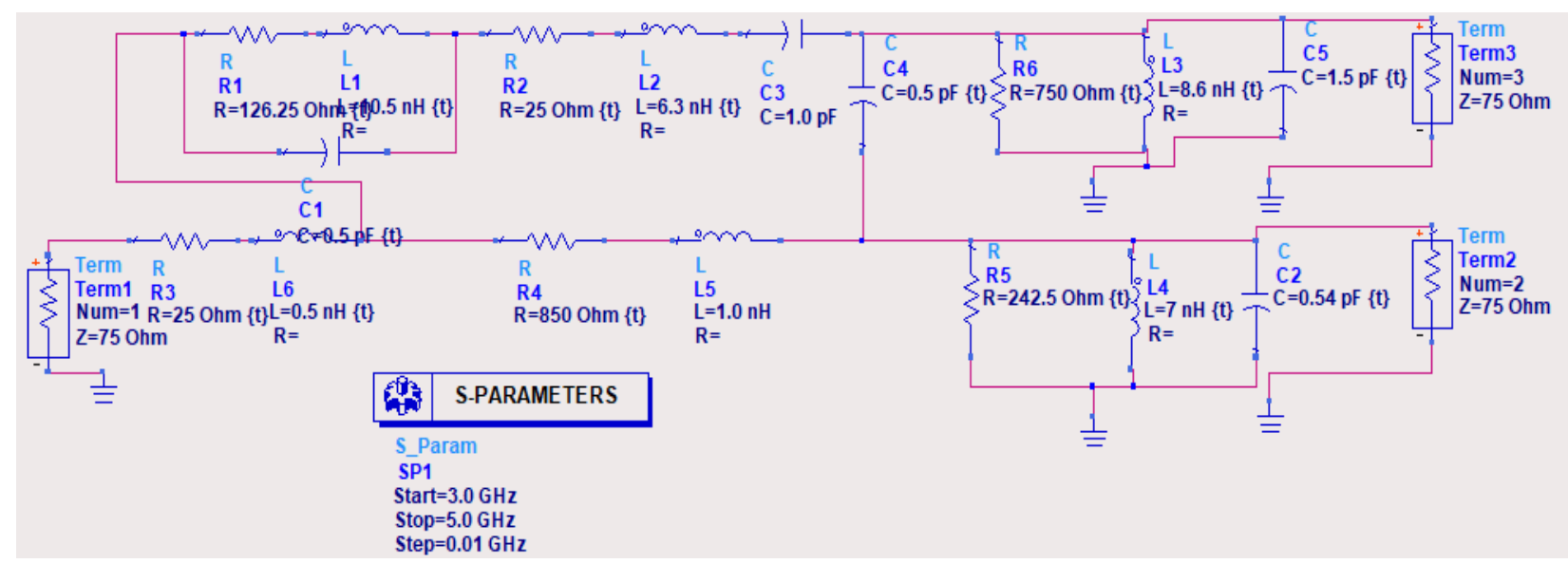

Fig. 3 - Equivalent circuit of the proposed antenna

Typical discontinuities of a loaded patch and ground antenna as shown in Fig. 1, are slot and notches.

These discontinuities give rise to very small capacitances and inductances. Especially the reactance of these elements becomes significant at high microwave and millimeter-wave frequencies.

The approximated lumped value in the equivalent circuit of slot discontinuities can be given by Eqs. (18) and (19).

$$
\begin{gathered}
C_{s}=0.00137 h \frac{\sqrt{\varepsilon_{r e l}}}{Z_{c_{1}}}\left(1-\frac{W_{2}}{W_{1}}\right) \times \\
\times\left(\frac{\varepsilon_{r e l}+0.3}{\varepsilon_{r e l}-0.258}\right)\left(\frac{\frac{W_{1}}{h}+0.264}{\frac{W_{1}}{h}+0.8}\right)(p F), \\
L_{S}=\frac{L_{W_{1}}}{L_{W_{1}}+L_{W_{2}}} L .
\end{gathered}
$$

All of the slots and impedance matching capacitance, inductance and resistance together with the equivalent circuitry of patch and discontinuities are depicted in the Fig. 3.

\section{RESULTS AND DISCUSSION}

The simulated results of the proposed antenna are shown in Fig. 4. The results show that the proposed antenna has a bandwidth of about $0.7 \mathrm{GHz}$ (3.6$4.3 \mathrm{GHz}$ ). An equivalent circuit for the same antenna is carried out by ADS. From Fig. 4 the bandwidth of the antenna equivalent circuit is about $1.1 \mathrm{GHz}$ (3.3$4.4 \mathrm{GHz}$ ). It can be concluded that the reposed equiva- lent circuit is a good model for the 5G path antenna considered in this work.

In Fig. 5, we depicted the VSWR of the proposed design. From Fig. 5, we observe that the proposed design has good match because the value of VSWR is less than 2 in the operating band.

In Fig. 6, the variations of the real and imaginary parts of the antenna input impedance are presented. At the resonance frequency the real part is near to $50 \Omega$ and the imaginary part equal to 0 which mean that the proposed antenna is efficient in terms of reflected power against transmitted power.

In Fig. 7 the simulated radiation patterns are shown at operation frequency for the proposed antenna. In the $E$-plane, the maximum radiation is observed at $45^{\circ}$ while in the $H$-plane the main beam is directed $-60^{\circ}$. The proposed antenna exhibits overall good performance for both simulated.

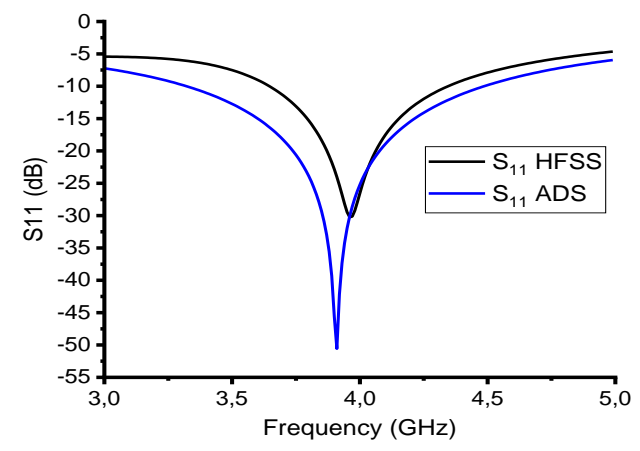

Fig. $4-S_{11}$ for the proposed antenna 


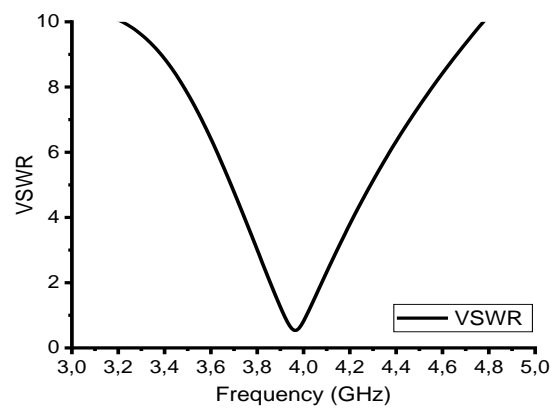

Fig. 5 - VSWR for the proposed antenna

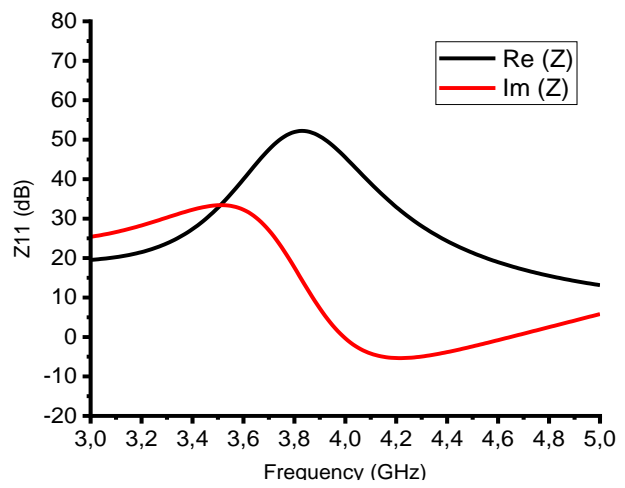

Fig. 6 - Real and imaginary parts of the proposed antenna input impedance

\section{REFERENCES}

1. Mordecai F. Raji, et al., Sci. Program. 2020, 3204695 (2020).

2. J. Belkadid, A. Benbassou, M. El Ghzaoui, International Journal on Communications Antenna and Propagation (IRECAP) 3 No 5, 267 (2013).

3. Y. Li, M. Zhang, W. Zhu, M. Cheng, C. Zhou, Y. Wu, China Commun. 17 No 1, 151 (2020).

4. M. El Ghzaoui, A. Hmamou, J. Foshi, J. Mestoui, J. Circ. Syst. Comp. 29 No 16, 2050257 (2020).

5. M. Nabil, M.M.A. Faisal, Wireless Pers. Commun. 116, 2761 (2021).

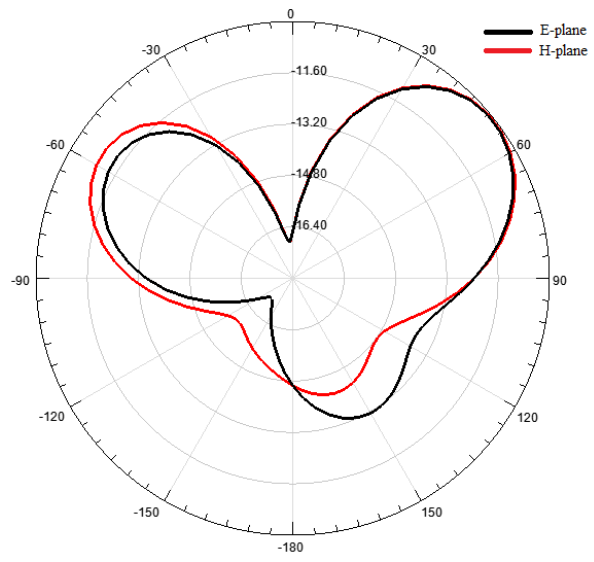

Fig. $7-E$-plane and $H$-plane of the proposed antenna input impedance

\section{CONCLUSIONS}

The proposed antenna with slotted microstrip patch and ground plane fed by $50 \mathrm{Ohm}$, microstrip feed line using lumped port excitation is successfully designed and simulated on two software's (HFSS \& ADS) in order to validate the model. The designed antenna shows high simulated bandwidth for the $5 \mathrm{G}$ wireless communication.

6. Bilal Aghoutane, et al., J. Circuit, System. Comput. 30, No 5, 2150086 (2021)

7. H. Raihani, A. Benbassou, M. El Ghzaoui, J. Belkadid, 2017 International Conference on Wireless Technologies, Embedded and Intelligent Systems (WITS), 1 (2017).

8. B. Aghoutane, M. El Ghzaoui, H. El Faylali, SN Appl. Sci. 3, 233 (2021).

9. C.A. Balanis, Antenna Theory: Analysis and Design, 4th Ed. (Wiley, Hoboken: NJ: 2016).

10. D.M. Pozar, Microwave Engineering, 2nd Ed. (Wiley \& Sons, Inc.: New York, USA: 1998).

\title{
Дослідження моделі еквівалентної схеми для мікросмугової патч-антени 5G
}

\author{
Bilal Aghoutane ${ }^{1}$, Mohammed El Ghzaoui ${ }^{2}$, Hanan El Faylali¹, Sudipta Das ${ }^{3}$ \\ ${ }^{1}$ ISO Laboratory, Department of Computer Science, Ibn Tofail University, Kenitra, Morocco \\ ${ }^{2}$ Faculty of Sciences, Sidi Mohamed Ben Abdellah University, Fes, Morocco \\ ${ }^{3}$ Department of ECE, IMPS College of Engineering and Technology, W.B., India
}

В останні роки ми спостерігаемо експоненщіальний розвиток нових додатків та технологій у галузі охорони здоров'я, ЗМІ, промисловості, транспорту, енергетики. Ця еволюція йде рука об руку з появою нових послуг, пов'язаних зі збільшенням кількості зв'язаних об’ектів. Зіткнувшись з цими викликами, настае нова ера з новим стандартом мобільних телекомунікаційних систем, так званою технологіею 5G. Робота представляе дослідження моделі еквівалентної схеми для мікросмугової патч-антени 5G. Метою даної роботи є моделювання антени з електричною схемою. Для цього запропонована антена була сконструйована двома методами, а потім порівняно коефіціенти $S_{11}$. По-перше, антена була розроблена програмним забезпеченням HFSS (High Frequency Structure Simulator). Потім та сама антена була спроектована за допомогою еквівалентної схеми, використовуючи інструмент оптимізації в програмному забезпеченні ADS (Advanced design system). Результати, отримані від двох програм, порівнювали за коефіціентом відбиття, тобто $S_{11}$. Було продемонстровано, що результати ADS добре узгоджуються з результатами HFSS. В роботі обговорюються і інші параметри, такі як VSWR (Voltage Standing Wave Ratio), $E$-площина і $H$-площина запропонованої антени, а також реальна та уявна частини вхідного опору антени. 3 результатів моделювання можна зробити висновок, що запропонована еквівалентна схема підтверджена за допомогою моделювання.

Ключові слова: Антена, Додатки 5G, Еквівалентна схема, Коефіцієнт відбиття 